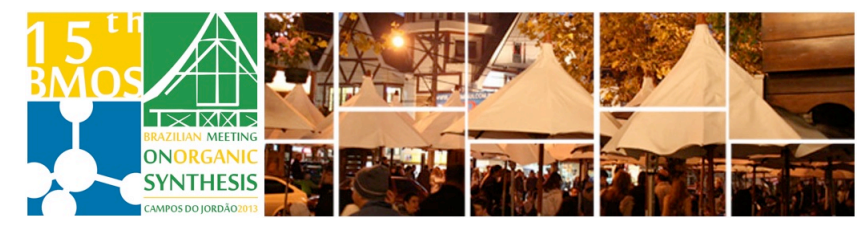

\title{
Novel Nano-Structured Chemosensors in Organic and Aqueous Phase
}

\author{
Javier Fernández-Lodeiro, ${ }^{\mathrm{a}, \mathrm{b}^{*}}$ Cristina Núñez, ${ }^{\mathrm{a}, \mathrm{c}}$ Adrián Fernández-Lodeiro, ${ }^{\mathrm{a}}$ \\ Elisabete Oliveira, ${ }^{\mathrm{a}}$ Hugo M. Santos, ${ }^{\text {a }}$ Alcindo A. Dos Santos, ${ }^{\mathrm{b}}$ José Luis Capelo, ${ }^{\mathrm{a}}$ \\ Carlos Lodeiro ${ }^{\mathrm{a}}$
}

\author{
${ }^{a}$ BIOSCOPE Group, REQUIMTE-CQFB, Chemistry Department, Faculty of Science and Technology, \\ University NOVA of Lisbon, Caparica Campus, 2829-516, Portugal \\ ${ }^{b}$ Instituto de Química, Universidade de São Paulo, Av. Prof. Lineu Prestes, 748, CxP. 26077, 05508-000 São \\ Paulo, Brazil \\ ${ }^{\mathrm{C} E c o l o g y}$ Research Group, Department of Geographical and Life Sciences, Canterbury Christ Church \\ University, CT1 1Q U, Canterbury, United Kingdom \\ *e-mail: j.lodeiro@campus.fct.unl.pt
}

Keywords: AuNPs, AgNPs, chemosensor

\section{INTRODUCTION}

Noble metal nanoparticles (MNPs) have been intensively pursued in recent years, not only for their fundamental scientific interest ${ }^{1}$ but also for their technological applications, in analytical sensors, catalysis or fuel cells. ${ }^{2}$ Several experimental routes have been recently proposed to efficiently selfassemble preformed MNPs into 1D chains. ${ }^{3}$

\section{RESULTS AND DISCUSSION}

Here we present new emissive materials (see Figure 1) and functionalized nanoparticles in order to explore their applications in 1D-chain formationchemosentors. ${ }^{4}$

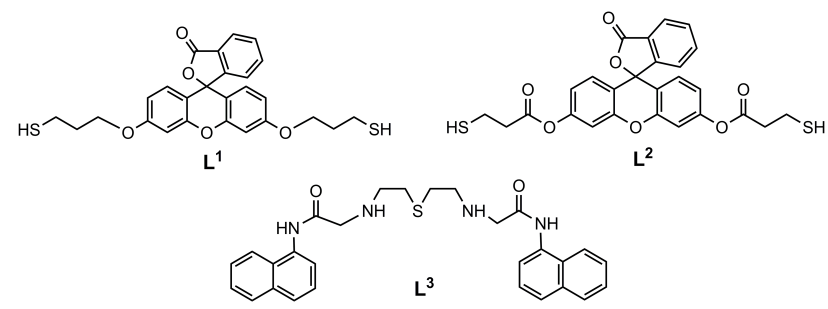

Figure 1. Schematic representation of compounds $L^{1}-L^{3}$.

Changes in the surface Plasmon resonance (SPR) bands as well as colours due to the network of 1D assemblies of nanoparticles were observed (Figure 2). The chelation interaction of the $\mathrm{Hg}^{2+}$ ions with the carboxylate groups of chemosensor $\mathrm{L}^{1}$ or the amine in L3 located in the AuNPs and AgNPs surface is the responsible of the selective formation of chains between the NPs modulated for the $\mathrm{Hg}^{2+}$ metal ions and viceversa.

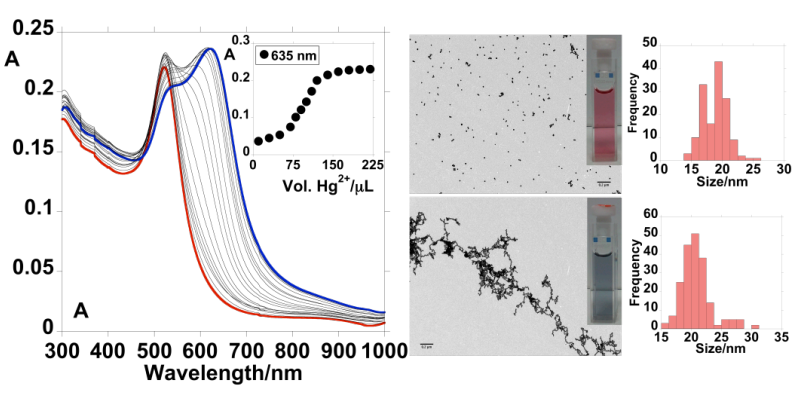

Figure 2. Spectrophotometric titration of AuNPs@L ${ }^{1}$ with the addition of increasing amounts of $\mathrm{Hg}\left(\mathrm{NO}_{3}\right)_{2}$ in aqueous solution (left). Naked eye detection and TEM images of AuNPs@L with the addition of 200 $\mu \mathrm{L}$ of $\left[\mathrm{Hg}\left(\mathrm{NO}_{3}\right)_{2}\right]=1.00 \times 10^{-3} \mathrm{M}$ (right).

\section{ACKNOWLEDGEMENTS}

We are grateful to Scientific Association ProteoMass (Portugal), Xunta de Galicia (Spain) for a research contract under project 09CSA043383PR (JFL) and I2C postdoctoral program (C.N). Authors are also grateful for the financial and structural support offered by the University of São Paulo through the NAP-CatSinQ (Research Core in Catalysis and Chemical Synthesis) and FAPESP for financial support.

\section{REFERENCES}

a) J. Fernández-Lodeiro et al., J. Nanoparticle Res.,. 2013, 15, 1828.

${ }^{2}$ a) Hutchings, G. J.; Brust, M.; Schmidbaur, H. Chem. Soc. Rev. 2008, 37, 1759. b) Guo, S.; Wang, E. Nano Today 2011, 6, 240.

3 DeVries, G. A.; Brunnbauer, M.; Hu, Y.; Jackson, A. M.; Long, B.; Neltner, B. T.; Uzun, O.; Wunsch, B. H.; Stellacci, F. Science 2007, 315, 358.

${ }^{4}$ (a) Lodeiro, C.; et al Chem. Soc. Rev. 2010, 39, 294. 